\title{
Pengaruh Rasio Aktivitas Terhadap Profitabilitas (pada Perusahaan Pertambangan yang Terdaftar Di Bursa Efek Indonesia Periode 2010-2018)
}

\author{
Dirvi Surya Abbas ${ }^{(1)}$, \\ Universitas Muhammadiyah Tangerang \\ abbas.dirvi@gmail.com \\ Januar Eky Pambudy ${ }^{(2)}$ \\ Universitas Muhammadiyah Tangerang \\ Jep@umt.ac.id
}

\begin{abstract}
This study aims to determine the effect of several factors that affect profitability in the company based on financial statements. This research is a causal research or research which states that one variable affects the other variables. The variables that influence are called the independent variables in this study, namely Turnover Receivable, Turnover Inventory, Turnover Working Capital, Turnover of Total Assets, Profitability. The affected variable is called the dependent variable and in this study is Profitability.

The method in sampling uses purposive sampling and uses panel data regression as a research test tool. The sample used is the Mining company listed on the IDX. The results of data selection using purposive sampling method stated that the sample used in this study was 7 companies and because it used a 9-year study period, the number of samples was 62 samples. The results of this study indicate that Receivable Turnover, Inventory Turnover, Working Capital Turnover have no effect on Profitability, then Total Asset Turnover has a positive and significant effect on Profitability.
\end{abstract}

\begin{abstract}
ABSTRAK
Penelitian ini bertujuan untuk mengetahui pengaruh dari beberapa faktor yang mempengaruhi Profitabilitas yang berada diperusahaan berdasarkan laporan keuangan. Penelitian ini merupakan penelitian yang bersifat kausal atau penelitian yang menyatakan satu variabel mempengaruhi variabel yang lain. Variabel yang mempengaruhi disebut variabel independen yang dalam penelitian ini yaitu Turnover Receivable, Turnover Inventory, Turnover Working Capital, Turnover Total Asset, Profitabilitas. Variabel yang terpengaruh disebut variabel dependen dan dalam penelitian ini yaitu Profitabilitas.

Metode dalam pengambilan sampel menggunakan purposive sampling dan menggunakan regresi data panel sebagai alat uji penelitian. Sampel yang digunakanya itu perusahaan Pertambangan yang terdaftar di BEI. Hasil dari seleksi data dengan menggunakan metode purposive sampling menyatakan bahwa sampel yang digunakan dalam penelitian ini sebanyak 7 perusahaan dan dikarenakan menggunakan rentang waktu penelitian 9 tahun maka jumlah sampel yang ada 62
\end{abstract}


sampel. Hasil penelitian ini menunjukkan bahwa Receivable Turnover, Inventory Turnover, Working Capital Turnover tidak berpengaruh terhadap Profitabilitas, lalu Total Asset Turnover berpengaruh Positif dan signifikan terhadap Profitabilitas.

Kata kunci : Receivable Turnover, Inventory Turnover, Working Capital Turnover, Total Asset Turnover, Profitabilitas.

\section{PENDAHULUAN}

Kinerja keuangan suatu perusahaan dapat diartikan sebagai prospek atau masa depan, pertumbuhan potensi perkembangan yang baik bagi perusahaan. Informasi kinerja keuangan diperlukan untuk menilai perubahan potensial sumberdaya ekonomi, yang mungkin dikendalikan dimasa depan dan untuk memprediksi kapasitas produksi dari sumber daya yang ada. Sedangkan laporan keuangan yang telah dianalisis sangat diperlukan pemimpin dalam sebuah perusahaan atau manajemen untuk dijadikan sebagai alat pengambilan keputusan lebih lanjut untuk masa yang akan datang.

Terdapat fenomena yang berkaitan dengan profitabilitas salah satunya pada perusahaan pertambangan di Indonesia sebagai berikut. Merosotnya nilai saham pada PT Bumi Resources Tbk (BUMI) membuat kapitalisasi pasar atau nilai perusahaan tinggal Rp 2,8 triliun. Harga sahamnya ada di kisaran Rp 79 per lembar. Nilai kapitalisasi pasar tersebut dikutip dari data perdagangan Bursa Efek Indonesia (BEI). Jika melihat titik tertingginya di Rp 8.750 per lembar yang diraih pada 10 Juni 2008, kapitalisasi saham BUMI dengan asumsi saham beredar saat ini 36,63 miliar lembar bisa mencapai Rp 320 triliun. Kapitalisasi pasarnya menjadi yang paling tinggi di antara perusahaanperusahaan batu bara lainnya di lantai bursa saat ini. Bahkan dapat mengalahkan kapitalisasi pasar perusahaan termahal di bursa saat ini yaitu PT Astra Internasional Tbk (ASII) senilai Rp 284 triliun. Namun angka tersebut tidak bisa dibandingkan karena posisi tertinggi saham BUMI itu diraih sebelum krisis finansial global tahun 2008. Setelah situasi krisis, harga saham-saham semua menjadi anjlok. Saat saham-saham lain bisa bangkit lagi setelah krisis, termasuk saham Astra, tetapi tidak berlaku untuk ratarata saham Grup Bakrie.

Pada fenomena yang telah peneliti jelaskan diatas terdapat pengaruh yang signifikan terhadap profitabilitas. Karena terdapat suatu fenomena dimana PT Bakrie and Brother telah gagal dalam membayar hutang-hutangnya, dikarenakan terjadinya penurunan tajam pada harga batu bara di dunia. Hal ini membuat harga saham pada Grup Bakrie tertekan sejak tahun 2011. Jika jumlah beban yang dibayar lebih tinggi dari laba usaha yang didapat, maka hal ini memperlihatkan buruknya kemmampuan untuk membayar hutang, baik itu hutang jangka pendek maupun jangka panjangnya.

Rasio keuangan mempunyai kemampuan dalam memprediksi laba yang akan diperoleh perusahaan dimasa depan, rasio tersebut adalah: rasio profitabilitas, rasio likuiditas, dan rasio aktivitas, maka peneliti menggunakan salah satu dari rasio keuangan yaitu rasio aktivitas. Rasio aktivitas menunjukkan bagaimana sumber daya telah digunakan secara optimal oleh perusahaan. Pemanfaatan aset oleh manajemen dapat dianalisis dalam hubungannya dengan tingkat laba yang dirumuskan dengan berbagai aset yang akan dipakai dalam memperoleh laba. 
Berdasarakan dari fenomena dan motivasi diatas peneliti menarik kesimpulan untuk melakukan penelitian ini. Penelitian ini juga mengambil sampel pada sektor pertambangan yang terdaftar di Bursa Efek Indonesia pada periode antara tahun 20102018. Penelitian ini mengambil sampel dari Bursa Efek Indonesia bertujuan untuk menjaga kesesuaian penelitian dengan praktiknya yang terdapat di beberapa tahun belakangan ini.

\section{TINJAUAN PUSTAKA}

\section{Hipotesis Penelitian}

Pengaruh Receivable Turnover terhadap Profitabilitas

Signaling theory mengemukakan bagaimana seharusnya sebuah perusahaan memberikan sinyal kepada pengguna laporan keuangan, demikian halnya dengan perputaran piutang yang dapat memberikan sinyal pada pengguna laporan keuangan karena aktivitasnya didalam sebuah perusahaan. Berdasarkan penelitian yang dilakukan oleh I Gusti Ayu Putu Istri Widya Santhi dan Sayu Ketut Sutrisna Dewi (2014) menyatakan bahwa Receivable Turnover berpengaruh positif terhadap profitabilitas. hasil penelitian tersebut diperkuat dengan hasil penelitian Mohamad Tejo Suminar (2014) menyatakan bahwa Receivable Turnover juga berpengaruh positif terhadap nilai perusahaan. Berdasarkan teori signaling dengan hasil penelitian terdahulu maka hipotesis yang akan diajukan adalah sebagai berikut:

\section{$\mathrm{H}_{1}$ : Receivable Turnover berpengaruh positif terhadap Profitabilitas}

\section{Pengaruh Inventory Turnover terhadap Profitabilitas}

Perusahaan perlu memberikan informasi kepada investor melalui penerbitan laporan keuangan karena keputusan yang akan diambil investor dipengaruhi oleh kualitas informasi yang diungkapkan perusahaan melalui laporan keuangannya, demikian halnya dengan Inventory Turnover yang dapat memberikan sinyal pada pengguna laporan keuangan karena aktivitasnya didalam sebuah perusahaan. Erik Pebrin Naibaho dan Sri Rahayu (2013) telah meneliti hubungan perputaran persediaan yang berpengaruh positif terhadap nilai perusahaan. Berdasarkan hasil penelitian diatas diperkuat dengan hasil penelitian Eka Ayu Rahayu dan Joni Susilowibowo (2014) menyatakan bahwa Inventory Turnover juga berpengaruh positif terhadap nilai perusahaan. Berdasarkan teori signaling dengan hasil penelitian terdahulu maka hipotesis yang akan diajukan sebagai berikut :

\section{H2: Inventory Turnover berpengaruh positif terhadap Profitabilitas}

\section{Pengaruh Working Capital Turnover terhadap Profitabilitas}

Teori sinyal mengemukakan tentang bagaimana seharusnya perusahaan memberikan sinyal-sinyal pada pengguna laporan keuangan untuk setiap aktivitas yang dilakukan oleh perusahaan. Working Capital Turnover dapat memberikan sinyal terhadap pengguna laporan keuangan sebagai acuan para investor untuk berinvestasi di perusahaan. Pada penelitian hasil penelitian yang dilakukan oleh Ni Wayan Yuliati (2012) secara persial menunjukkan adanya pengaruh positif terhadap profitabilitas. Demikian pula dengan hasil penelitian yang dilakukan oleh Mulatsih (2014) menyatakan bahwa Working Capital Turnover berpengaruh positif terhadap profitabilitas. Berdasarkan uraian diatas maka hipotesis yang dapat diajukan dalam penelitian ini adalah:

H3: Working Capital Turnover berpengaruh positif terhadap Profitabilitas 


\section{Pengaruh Total Asset Turnover terhadap Profitabilitas}

analisis Du Pont penting bagi manajer untuk mengetahui faktor mana yang paling kuat pengaruhnya antara profit margin dan Total Asset Turnover terhadap profitabilitas. Disamping itu dengan menggunakan analisis ini, pengendalian biaya dapat diukur dan efisiensi Total Asset Turnover sebagai akibat turun naiknya penjualan dapat diukur. Pada hasil penelitian yang dilakukan oleh Helmia Mabchut Nahdi, Jaryono dan Najmudin (2012) menunjukkan adanya pengaruh positif antara Total Asset Turnover dengan profitabilitas. Demikian pula dengan hasil penelitian yang dilakukan oleh Amrita Maulidia Rahmah, Wayan Cipta dan Fridayana Yudiaatmaja (2016) yang menyatakan bahwa Total Asset Turnover secara persial dan simultan berpengaruh positif dan signifikan terhadap profitabilitas. Berdasarkan uraian diatas maka hipotesis yang dapat diajukan dalam penelitian ini adalah:

\section{H4: Perputaran Total Asset Turnover berpengaruh positif terhadap Profitabilitas}

\section{METODE PENELITIAN \\ Populasi dan Sampel}

Populasi dalam penelitian ini adalah seluruh perusahaan pertambangan yang terdaftar pada Bursa Efek Indonesia (BEI) selama periode 2010-2018. Kriteria yang digunakan untuk memilih sampel adalah Perusahaan mempublikasikan laporan keuangan dengan lengkap periode 2010-2013 dan menggunakan nilai mata uang rupiah (Rp).

\section{Variabel Independen}

\section{Turnover Receivable $\left(\mathrm{X}_{1}\right)$}

Perputaran Piutang (Turnover Receivable) adalah kemampuan perusahaan dalam menangani penjualan kredit dan kebijakannya. Pengertian receivable di sini adalah Perputaran Piutang (Turnover Receivable). Seperti diketahui kebanyakan perusahaan menjualan secara kredit. Dengan penjualan kredit diharapkan total penjualan meningkat, laba meningkat dengan risiko juga meningkat. Penjualan kredit menciptakan peluang usaha. Risiko terjadi pada saat pembeli tidak mampu membayar atau menunda pembayaran (Prihadi, 2008). Semakin cepat perputaran berarti semakin sedikit dana yang perlu ditanam di dalam piutang usaha. Pada penelitian ini, perputaran piutang dihitung dengan menggunakan rumus :

$$
\mathbf{R T}=\frac{\text { Sales }}{\mathbf{A T R}}
$$

\section{Keterangan :}

RT : Receivable Turnover/Perputaran Piutang

Sales : Penjualan

ATR : Average Trade Receivable /Rata rata Piutang

\section{Inventory Turnover $\left(\mathrm{X}_{2}\right)$}

Menurut Rahayu (2014) rasio perputaran persediaan adalah beberapa kali barang di jual dan diadakan kembali selama atu periode tertentu. rasio perputaran persediaan merupakan perbandingan antara harga pokok penjualan dengan persediaan rata-rata yang dimiliki perusahaan selama satu periode tertentu. rasio ini digunakan untuk mengukur seberapa jauh efisiensi perusahaan dalam mengelola dan menjual persediaannya. Rumus 
yang digunakan untuk mencari inventory turnover dapat digunakan dengan cara sebagai berikut :

$\mathrm{IT}=\frac{\mathrm{COGS}}{\mathrm{AI}}$

Keterangan :

IT :Inventory Turnover / Perputaran Persediaan

COGS : Cost of Goods Sold / Harga Pokok Penjualan

AI : Average Inventory/ Rata-rata Persediaan

Working Capital Turnover ( $\left.\mathrm{X}_{3}\right)$

Apabila utang lancar melebihi akiva lancar maka modal kerja akan negatif. Secara umum dikatakan bahwa perputaran semakin tinggi semakin baik (Prihadi, 2008).

WCT $=$ Sales

$\overline{\mathrm{AWC}}$

Keterangan :

WCT : Working Capital Turnover/Perputaran Modal Kerja

Sales : Penjualan

AWR : Average Working Capital/ Rata-rata Modal Kerja

\section{Total Asset Turnover $\left(\mathrm{X}_{4}\right)$}

Perputaran total aset merupakan ukuran keseluruhan perputaran seluruh asset. Rasio ini cukup sering digunakan karena cakupannya yang menyeluruh. Tanpa memandang jenis usaha, rasio ini dapat menggambarkan sampai seberapa baik dukungan seluruh asset untuk memperoleh penjualan (Prihadi, 2008).

TATO $=\underline{\text { Sales }}$

ATA

Keterangan :

TATO : Total Asset Turnover/Perputaran Total Aset

Sales : Penjualan

ATA : Average Total Asset / Rata-rata Total Asset

\section{Variabel Dependen}

Profitabilitas (Y)

Kemudian Return on Asset juga digunakan untuk mengukur efektifitas perusahaan dalam menghasilkan keuntungan yang diperoleh oleh perusahaan dengan memanfaatkan aktiva yang dimilikinya dan Return on Asset dapat mencerminkan tingkat efisiensi pengelolaan perusahaan. Pada penelitian ini, Return on Asset dihitung dengan menggunakan rumus :

ROA $=\frac{\text { EAT }}{\text { TA }}$ 
Keterangan :

ROA : Return on Asset

EAT : Earning After Tax

TA : Total Asset

\section{HASIL DAN PEMBAHASAN}

Hasil Analisis Statistik Deskriptif

\begin{tabular}{|c|c|c|c|c|c|}
\hline & $\begin{array}{l}\text { RETURN } \\
\text { ON ASET }\end{array}$ & $\begin{array}{c}\text { TURN_OVER } \\
\text { AR }\end{array}$ & $\begin{array}{l}\text { TURN_OVER } \\
\text { NVENTORY }\end{array}$ & $\begin{array}{l}\text { TUNR_OVER } \\
\text { WORK CAP }\end{array}$ & $\begin{array}{l}\text { TURN_OVER } \\
\text { TOTAL ASET }\end{array}$ \\
\hline Mean & 0.054516 & 589.2342 & 16.91952 & 3.435645 & 0.769677 \\
\hline Median & 0.055000 & 10.58000 & 5.430000 & 2.770000 & 0.830000 \\
\hline Maximum & 0.270000 & 23162.98 & 301.4300 & 14.52000 & 1.490000 \\
\hline Minimum & -0.650000 & 0.890000 & -23.90000 & -2.980000 & 0.000000 \\
\hline Std. Dev. & 0.132945 & 3323.043 & 43.05080 & 3.091819 & 0.375613 \\
\hline Skewness & -2.696639 & 5.954719 & 5.184004 & 1.317733 & -0.427363 \\
\hline Kurtosis & 15.06801 & 38.31944 & 33.16730 & 5.634836 & 2.533249 \\
\hline Jarque-Bera & 451.3709 & 3589.019 & 2628.700 & 35.87743 & 2.450064 \\
\hline Probability & 0.000000 & 0.000000 & 0.000000 & 0.000000 & 0.293748 \\
\hline Sum & 3.380000 & 36532.52 & 1049.010 & 213.0100 & 47.72000 \\
\hline Sum Sq. Dev. & 1.078135 & $6.74 \mathrm{E}+08$ & 113055.7 & 583.1201 & 8.606194 \\
\hline Observations & 62 & 62 & 62 & 62 & 62 \\
\hline
\end{tabular}

a. Berdasarkan tabel diatas dapat dideskripsikan bahwa Profitabilitas sebagai variabel dependen (y) memiliki nilai terendah $-0,65$ dan nilai tertinggi 0,27 nilai rata-rata (mean) sebesar 0,054 dengan standar deviasi sebesar 0,132 . Nilai mean sebesar 0,054 (5,4\%) menunjukkan bahwa rata-rata Profitabilitas perusahaan-perusahaan sampel yang diteliti adalah sebesar 5,4\% dari total kualitas laba. Standar deviasi sebesar 13,29\% menunjukkan bahwa Profitabilitas dari perusahaan-perusahaan sampel yang diteliti memiliki perbedaan yang relative kecil.

b. Variabel Receivable Turnover (X1) memiliki nilai minimum 0,89 dan nilai maksimum 23162,98 nilai mean sebesar 589,2342 dan standar deviasi sebesar 3323,043, hal ini menunjukkan bahwa 5,89\% rata-rata Receivable Turnover. Standar deviasi sebesar $33,23 \%$ menunjukkan total profitabilitas dari perusahaan-perusahaan sampel yang diteliti memiliki perbedaan yang relatif besar.

c. Variabel Inventory Turnover $\left(\mathrm{X}_{2}\right)$ memiliki nilai minimum -23,90 dan nilai maksimum 301,43, nilai mean sebesar 16,919 dan standar deviasi sebesar 43,050. Hal ini menunjukkan bahwa $16,9 \%$ rata rata ukuran perusahaan. Standar deviasi sebesar 43,05\% menunjukkan Inventory Turnover dari perusahaan - perusahaan sampel yang diteliti memiliki perbedaan yang relatif besar.

d. Variabel Working Capital Turnover $\left(\mathrm{X}_{3}\right)$ memiliki nilai minimum -2,98 dan nilai maksimum 14,52, nilai mean sebesar 3,437 dan standar deviasi sebesar 3,092. Hal ini menunjukkan bahwa rata-rata Working Capital Turnover sebesar 2,44\% dari perusahaan-perusahaan yang dijadikan sampel penelitian. Standar deviasi sebesar 3,09\% menunjukkan Working Capital Turnover pada perusahaan-perusahaan sampel yang diteliti memiliki perbedaan relatif kecil.

e. Variabel Total Asset Turnover $\left(\mathrm{X}_{4}\right)$ memiliki nilai minimum 00,00 dan nilai maksimum 1,49, nilai mean sebesar 0,77 dan standar deviasi sebesar 0,376. Hal ini menunjukkan bahwa rata-rata Total Asset Turnover sebesar 7,69\% dari perusahaanperusahaan yang dijadikan sampel penelitian. Standar deviasi sebesar 3,76\% 
menunjukkan Total Asset Turnover pada perusahaan-perusahaan sampel yang diteliti memiliki perbedaan yang relatif kecil.

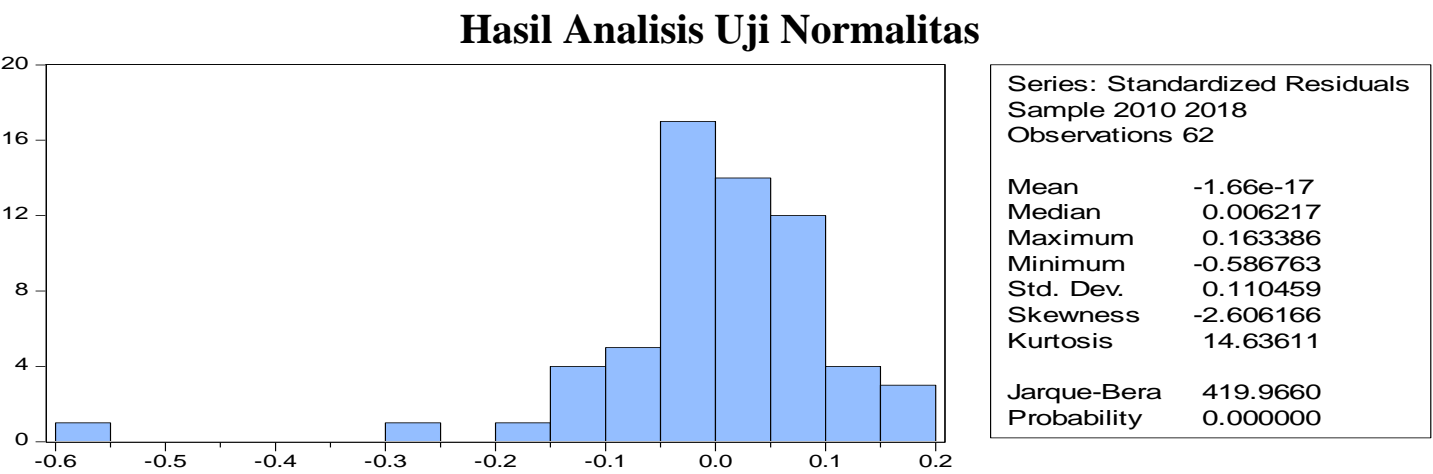

nilai jarque bera sebesar 419,9660 dengan $p$ value sebesar 0,0000 dimana $<0,05$ sehingga terima $\mathrm{H}_{1}$ atau yang berarti residual berdistribusi normal.

\section{Pemilihan Model Estimasi Model Uji Chow}

Uji chow digunakan untuk memilih model yang digunakan apakah sebaiknya menggunakan Common Effect Model (CEM) atau Fixed Effect Model (FEM). Pengujian ini dapat dilihat pada nilai Probabilitas (Prob.) Cross-section F dan Cross-section chi Square dengan hipotesis sebagai berikut:

H0 : Model mengikuti Common Effect Model (CEM) jika Probabilitas cross-section F dan Cross-section chi-square $>\alpha(0,05)$

Ha : Model mengikuti Fixed Effect Model (FEM) jika Probabilitas cross-section F dan Cross-section chi-square $<\alpha(0,05)$.

Adapun hasil uji chow sebagai berikut:

\section{Hasil Uji Chow}

\begin{tabular}{|c|c|c|c|}
\hline Effects Test & Statistic & d.f. & Prob. \\
\hline Cross-section F & 2.286801 & $(6,51)$ & 0.0496 \\
\hline Cross-section Chi-square & 14.771938 & 6 & 0.0221 \\
\hline
\end{tabular}

Sumber: Hasil Olahan Eviews 9.0, 2019

Dalam tabel di atas terlihat nilai probabilitas Cross-section $\mathrm{F}$ adalah 0, 0,049 $<\alpha$ $(0,05)$ dan Cross-section chi square adalah $0,022<\alpha(0,05)$, maka dapat disimpulkan bahwa Fixed Effect Model (FEM) lebih layak digunakan dibandingkan Common Effect Model (CEM). 


\section{Uji Hausman}

Uji hausman digunakan untuk memilih model yang digunakan apakah sebaiknya menggunakan Random Effect Model (REM) atau Fixed Effect Model (FEM). Pengujian ini dapat dilihat pada nilai Probabilitas (Prob.) Cross-section random dengan hipotesis sebagai berikut:

H0: Model mengikuti Random Effect Model (REM) jika nilai Probabilitas (Prob.) crosssection random $>\alpha(0,05)$

Ha: Model mengikuti Fixed Effect Model (FEM) jika nilai Probabilitas (Prob.) crosssection random $<\alpha(0,05)$

Adapun hasil uji hausman sebagai berikut:

\section{Hasil Uji Hausman}

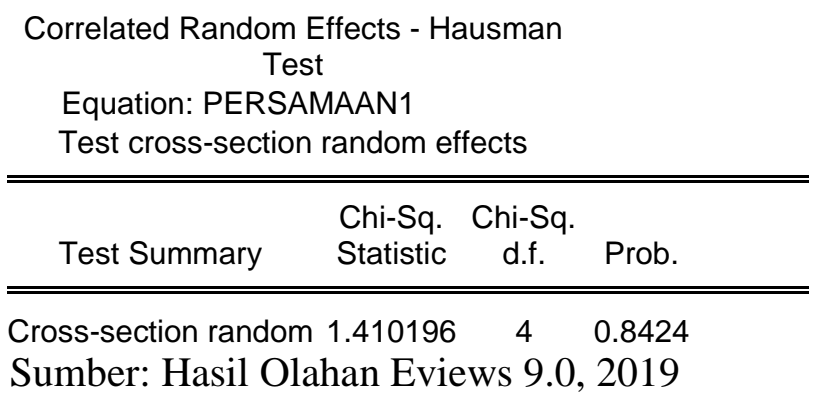

Dalam tabel di atas terlihat nilai probabilitas cross section random $>\alpha(0,05)$, maka dapat disimpulkan bahwa Random Effect Model (REM) lebih layak digunakan dibandingkan Fixed Effect Model (FEM).

\section{Uji Lagrange Multiplier}

Uji Langrange Multiplier digunakan untuk memilih model yang digunakan apakah sebaiknya menggunakan Commond Effect Model (CEM) atau Random Effect Model (REM). Pengujian ini dapat dilihat pada nilai Probabilitas Breush-pagan dengan hipotesis sebagai berikut:

H0 : Model mengikuti Commond Effect Model (CEM) jika nilai Probabilitas crosssection Breush-pagan $>\alpha(0,05)$

Ha : Model mengikuti Random Effect Model (REM) jika ka nilai Probabilitas crosssection Breush-pagan $<\alpha(0,05)$.

Adapun hasil uji Langrange Multiplier sebagai berikut:

\section{Hasil Uji Langrange Multiplier}

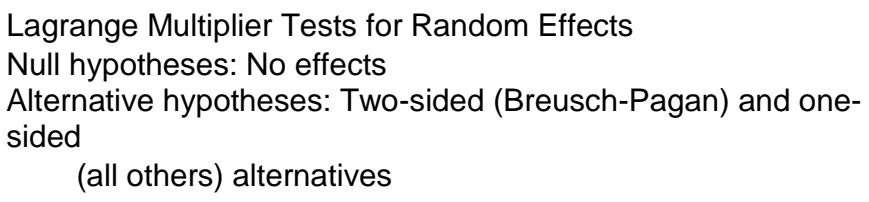




\begin{tabular}{cccc} 
& \multicolumn{3}{c}{ Test Hypothesis } \\
& Cross-section & Time & Both \\
\hline \hline Breusch-Pagan & $\begin{array}{l}2.483886 \\
(0.1150)\end{array}$ & $\begin{array}{l}0.884706 \\
(0.3469)\end{array}$ & $\begin{array}{l}3.368592 \\
(0.0665)\end{array}$
\end{tabular}

Sumber: Hasil Olahan Eviews 9.0, 2019

Berdasarkan hasil perhitungan diatas nilai probabilitas Cross-section Breuschpagan > $\alpha(0,05)$, maka dapat disimpulkan bahwa Cem Effect Model (CEM) lebih layak digunakan dibandingkan Random effect Model (REM).

\section{Common Effect Model}

Common Effect Model merupakan pendekatan model panel yang paling sederhana karena hanya mengkombinasikan data time series dan cross section. Pada model ini tidak diperhatikan dimensi waktu maupun individu, sehingga diasumsikan bahwa perilaku data perusahaan sama dalam berbagai kurun waktu. Metode ini bisa menggunakan pendekatan Ordinary Least Square (OLS) atau tekhnik kuadrat terkecil untuk mengestimasi model data panel (Basuki dan Prawoto; 2016).

Bentuk estimasi Common Effect Model adalah sebagai berikut:

\section{Common Effect Model}

\begin{tabular}{|c|c|c|c|c|}
\hline \multicolumn{5}{|c|}{ Dependent Variable: RETURN_ON_ASET } \\
\hline \multicolumn{5}{|c|}{ Method: Panel Least Squares } \\
\hline \multicolumn{5}{|l|}{ Date: 06/30/19 Time: 08:16 } \\
\hline \multicolumn{5}{|l|}{ Sample: 20102018} \\
\hline \multicolumn{5}{|l|}{ Periods included: 9} \\
\hline \multicolumn{5}{|l|}{ Cross-sections included: 7} \\
\hline \multicolumn{5}{|c|}{ Total panel (unbalanced) observations: 62} \\
\hline Variable & Coefficient & Std. Error & t-Statistic & Prob. \\
\hline $\mathrm{C}$ & -0.090144 & 0.033406 & -2.698452 & 0.0091 \\
\hline TURN_OVER_AR & $-2.81 E-06$ & $4.51 \mathrm{E}-06$ & -0.623433 & 0.5355 \\
\hline TURN_OVER_INVENTORY & -0.000187 & 0.000349 & -0.536199 & 0.5939 \\
\hline TUNR_OVER_WORK_CAP & -0.007740 & 0.005678 & -1.363180 & 0.1782 \\
\hline TURN_OVER_TOTAL_ASET & 0.228766 & 0.047072 & 4.859955 & 0.0000 \\
\hline R-squared & 0.309671 & \multicolumn{2}{|c|}{ Mean dependent var } & 0.054516 \\
\hline Adjusted R-squared & 0.261227 & \multicolumn{2}{|c|}{ S.D. dependent var } & 0.132945 \\
\hline S.E. of regression & 0.114269 & \multicolumn{2}{|c|}{ Akaike info criterion } & -1.423321 \\
\hline Sum squared resid & 0.744268 & \multicolumn{2}{|c|}{ Schwarz criterion } & -1.251778 \\
\hline Log likelihood & 49.12295 & \multicolumn{2}{|c|}{ Hannan-Quinn criter. } & -1.355969 \\
\hline F-statistic & 6.392335 & \multirow{2}{*}{\multicolumn{2}{|c|}{ Durbin-Watson stat }} & 1.784107 \\
\hline Prob(F-statistic) & 0.000254 & & & \\
\hline
\end{tabular}

Sumber: Hasil Olahan Eviews 9.0, 2019

\section{Kesimpulan Model}

Hasil pengujian disajikan dalam tabel sebagai berikut:

\section{Kesimpulan Uji}




\begin{tabular}{|c|l|l|c|}
\hline No. & \multicolumn{1}{|c|}{ Metode } & \multicolumn{1}{|c|}{ Pengujian } & Hasil \\
\hline 1 & Uji Chow & CEM vs FEM & FEM \\
\hline 2 & Uji Hausman & REM vs FEM & REM \\
\hline 3 & Uji Langrange Multiplier & CEM vs REM & CEM \\
\hline
\end{tabular}

Menurut Basuki dan Prawoto (2016) secara formal ada tiga prosedur pengujian estimasi data panel, yaitu uji statistik F yang digunakan untuk memilih antara:

1) Model common effects atau fixed effects

2) Uji Langrange Multiplier (LM) yang digunakan untuk memilih antara model common effects atau model random effects

3) Uji Hausman yang digunakan untuk memilih antara model fixed effects atau model random effects Dengan konsep demikian, apabila data OLS sudah dilakukan uji dengan uji chow maka hasilnya akan diuji lagi untuk menentukan data OLS atau GLS yang digunakan.

Berdasarkan hasil pengujian yang sudah dilakukan diketahui bahwa pada uji chow terpilih model FEM dengan nilai cross-section $f$ sebesar 0.0496 lebih kecil dari 0,05 dan pada uji hausman model yang terpilih adalah estimasi model REM dengan nilai cross section random sebesar 0.8424 lebih besar dari 0,05 . Lalu, pada uji Lagrange Multiplier model yang terpilih adalah estimasi model CEM dengan nilai Breusch-Pagan sebesar 0.1150 lebih besar dari 0,05. Maka dapat ditarik kesimpulan bahwa model estimasi yang akan digunakan dalam penelitian ini adalah model Common Effect Model (CEM).

\section{Uji Asumsi Klasik}

Dalam regresi data panel model yang berbasis Ordinary Least Squared (OLS) adalah Commont Effect Model (CEM) dan Fixed Effect Model (FEM), dengan demikian perlu dilakukan uji asumsi klasik apabila model regresi yang digunakan dalam bentuk adalah Commont Effect Model (CEM) dan Fixed Effect Model (FEM).

\section{Uji Multikolineritas}

Uji Multikolineritas perlu dilakukan pada regresi yang menggunakan lebih dari sat variabel bebas, hal ini untuk mengetahui apakah terjadi hubungan saling mempengaruhi antara variabel bebas yang diteliti.

\section{Hasil Uji Multikolineritas}

\begin{tabular}{|c|c|c|c|c|}
\hline & TURN_OVER_- & $\begin{array}{c}\text { TURN_OVER_INV } \\
\text { ENTORY }\end{array}$ & $\begin{array}{c}\text { TUNR_OVER_WO } \\
\text { RK_CAP }\end{array}$ & $\begin{array}{c}\text { TURN_OVER_TOT } \\
\text { AL_ASET }\end{array}$ \\
\hline TURN_OVER_AR & 1.000000 & 0.091761 & 0.201912 & 0.167132 \\
\hline TURN_OVER_INVENTORY & 0.091761 & 1.000000 & 0.145793 & 0.222128 \\
\hline TUNR_OVER_WORK_CAP & 0.201912 & 0.145793 & 1.000000 & 0.541445 \\
\hline TURN_OVER_TOTAL_ASET & 0.167132 & 0.222128 & 0.541445 & 1.000000 \\
\hline
\end{tabular}

Sumber: Hasil Olahan Eviews 9.0, 2019

Dari hasil diatas dapat dilihat tidak terdapat variabel independen yang memiliki nilai lebih dari 0.8 , sehingga dapat disimpulkan tidak terjadi multikolineritas dalam model regresi

\section{Uji Hipotesis \\ Uji $\mathbf{R}^{2}$ (Koefisien determinasi)}


Koefisien Determinasi merupakan cara untuk mengukur ketepatan suatu garis regresi. Menurut Gujarati (2001) bahwa koefisien determinasi yaitu angka yang menunjukkan besarnya derajat kemampuan menerangkan variabel bebas terhadap terikat dari fungsi tersebut. Hal tersebut dilakukan dengan cara pengukuran ketepatan suatu garis regresi dengan $\mathrm{R}^{2}$ yaitu angka yang menunjukkan besarnya derajat kemampuan menerangkan variabel bebas $\left(0<\mathrm{R}^{2}<1\right)$, dimana semakin mendekati 1 maka semakin dekat pula hubungan antar variabel bebas dengan variabel terikat atau dapat dikatakan bahwa model tersebut baik, demikian pula sebaliknya. Berikut hasil koefisien determinasi:

\section{Hasil Uji Koefisien Determinasi}

\begin{tabular}{|c|c|}
\hline R-squared & 0,309671 \\
\hline Sumber: Hasil Olahan Eviews 9.0, 2019
\end{tabular}

Hasil R-Squared pada model ini adalah 0,309671 artinya bahwa variasi perubahan naik turunnya Profitabilitas dapat dijelaskan oleh Receivable Turnover, Inventory Turnover, Working Capital Turnover dan Total Asset Turnover sebesar $30.96 \%$, sedangkan sisanya $69.04 \%$ disebabkan oleh variabel atau hal lain diluar dari variabel yg diteliti.

\section{Uji t Parsial}

Uji Parsial bertujuan untuk menguji pengaruh masing-masing variabel independen terhadap variabel dependen. Dari hasil uji t parsial dapat dilihat dari nilai masing-masing probabilitas tiap variabel.

Rumusan hipotesis yang digunakan dalam uji $\mathrm{F}$ adalah sebagai berikut:

1) Berdasarkan perbandingan $F$-statistic dengan $F$ Tabel

$\mathrm{H} 0$ : Jika nilai $t$-statistic $<\mathrm{t}$ tabel

Ha : Jika nilai $t$-statistic $>\mathrm{t}$ tabel

Jika $t$-statistic < t tabel, maka $\mathrm{H} 0$ diterima yang artinya variabel independen $(\mathrm{X})$ secara parsial tidak berpengaruh terhadap variabel dependen (Y). Namun sebaliknya, jika $t$-statistic > t tabel, maka Ha diterima artinya variabel independen (X) secara parsial berpengaruh terhadap variabel dependen (Y).

2) Berdasarkan Probabilitas

H0 : Jika nilai Prob. $>\alpha 0,05$

Ha : Jika nilai Prob. $<\alpha 0,05$

Jika nilai Prob. $>\alpha$ 0,05, maka H0 diterima yang artinya variabel independen (X) secara parsial tidak berpengaruh terhadap variabel dependen (Y). namun sebaliknya, Jika nilai Prob. < $\alpha$ 0,05, maka Ha diterima artinya variabel independen (X) secara parsial berpengaruh terhadap variabel dependen (Y). Berikut hasil dari uji t:

\section{Uji t (parsial)}

\begin{tabular}{ccccc} 
Variable & Coefficient & Std. Error & t-Statistic & Prob. \\
\hline \hline$C$ & -0.090144 & 0.033406 & -2.698452 & 0.0091
\end{tabular}




$\begin{array}{ccccc}\text { TURN_OVER_AR } & -2.81 E-06 & 4.51 E-06 & -0.623433 & 0.5355 \\ \text { TURN_OVER_INVENTORY } & -0.000187 & 0.000349 & -0.536199 & 0.5939 \\ \text { TUNR_OVER_WORK_CAP } & -0.007740 & 0.005678 & -1.363180 & 0.1782 \\ \text { TURN_OVER_TOTAL_ASET } & 0.228766 & 0.047072 & 4.859955 & 0.0000\end{array}$

Berdasarkan hasil uji t pada analisis resgresi panel menunjukan, maka dapat disimpulkan hasil hipotesis sebagai berikut:

1. Pengujian hipotesis pertama $\left(\mathrm{H}_{1}\right)$

Nilai Nilai t-statistic Receivable Turnover sebesar -0.623, sementara tabel dengan tingkat $\alpha=5 \%$, df $(\mathrm{n}-\mathrm{k})=62-4$ didapat nilai tabel sebesar 2.011. Dengan demikian tstatistic profitabilitas $(-0.623)<\mathrm{t}$ tabel $(2.011)$ dan nilai Prob. 0,5355 $>0,05$ maka dapat disimpulkan bahwa variabel Receivable Turnover dalam penelitian ini tidak memiliki pengaruh terhadap profitabilitas (ROA).

2. Pengujian hipotesis kedua $\left(\mathrm{H}_{2}\right)$

Nilai $t_{\text {-statistik }}$ Inventory Turnover sebesar -0.536 sementara $t_{\text {tabel }}$ dengan tingkat $\alpha=$ $5 \%$, df $(\mathrm{n}-\mathrm{k})=62-4$ didapat nilai $\mathrm{t}_{\text {tabel }}$ sebesar 2,011. Dengan demikian $\mathrm{t}_{\text {-statistic }}$ Inventory Turnover $(-0.5361)<\mathrm{t}_{\text {tabel }}(2,051)$ dan nilai Prob. $0.5939>0,05$ maka dapat disimpulkan bahwa variabel Inventory Turnover dalam penelitian ini tidak memiliki pengaruh terhadap profitabilitas (ROA).

3. Pengujian hipotesis ketiga $\left(\mathrm{H}_{3}\right)$

Nilai $\mathrm{t}_{\text {-statistik }}$ Working Capital Turnover sebesar -1.363 sementara $\mathrm{t}$ tabel dengan tingkat $\alpha=5 \%$, df $(\mathrm{n}-\mathrm{k})=62-4$ didapat nilai tabel sebesar 2,011. Dengan demikian $\mathrm{t}$ statistic Working Capital Turnover $(-1,363)<\mathrm{t}$ tabel $(2,011)$ dan nilai Prob. 0,1782 > 0,05 maka dapat disimpulkan bahwa variabel Working Capital Turnover dalam penelitian ini tidak memiliki pengaruh terhadap profitabilitas (ROA).

4. Pengujian hipotesis keempat $\left(\mathrm{H}_{4}\right)$

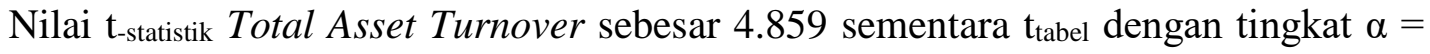
$5 \%$, df $(\mathrm{n}-\mathrm{k})=62-4$ didapat nilai $\mathrm{t}_{\text {tabel }}$ sebesar 2,011. Dengan demikian $\mathrm{t}_{\text {-statistic }}$ $(4,859)>t$ tabel $(2,011)$ dan nilai Prob. 0,0000 < 0,05 maka dapat disimpulkan bahwa variabel Total Asset Turnover dalam penelitian ini memiliki pengaruh positif terhadap profitabilitas (ROA).

\section{Persamaan Model Regresi Data Panel}

Fungsi persamaan regresi adalah untuk memprediksi nilai variabel dependen (Y) dan untuk mengetahui arah dan besarnya pengaruh variabel independen (X) terhadap variabel dependen (Y).

Berikut nilai coefficient yang diperoleh :

Nilai Coefficient

\begin{tabular}{|c|c|}
\hline Variabel & Coefficient \\
\hline C & -0.090144 \\
\hline AR & $-2.81 \mathrm{E}-06$ \\
\hline Inv & -0.000187 \\
\hline WorkCap & -0.007740 \\
\hline TotalAset & 0.228766 \\
\hline
\end{tabular}


Hasil persamaan regresi yang diperoleh adalah :

$$
\begin{gathered}
\mathrm{Y}=-0.090-2.813 \mathrm{AR}-0.000 \mathrm{INV}-0.007 \\
\text { WorkCap }+0.228 \text { TotalAset }+\mathrm{e}
\end{gathered}
$$

Persamaan regresi diatas memiliki makna sebagai berikut:

a. Konstanta $-0,090(0,090 \%)$ menyatakan bahwa jika variabel independen dianggap konstan, maka Profitabilitas (ROA) yang terjadi adalah sebesar -0,090 $(0,90 \%)$.

b. Receivable Turnover mempunyai koefisien regresi kearah negatif sebesar 2,813 $(28,13 \%)$. Hal ini berarti semakin rendah nilai Receivable Turnover perusahaan, maka Nilai Profitabilitas (ROA) akan semakin rendah.

c. Inventory Turnover mempunyai koefisien regresi kearah negatif sebesar 0,000 $(0,00 \%)$. Hal ini berarti semakin rendah nilai Inventory Turnover suatu perusahaan maka Nilai Profitabilitas (ROA) akan semakin rendah.

d. Working Capital Turnover mempunyai koefisien regresi kearah negatif sebesar $0,007(0,07 \%)$. Hal ini berarti semakin rendah nilai Working Capital Turnover suatu perusahaan maka Nilai Profitabilitas (ROA) akan semakin rendah.

e. Total Asset Turnover mempunyai koefisien regresi kearah positif sebesar 0,228 (22,8\%). Hal ini berarti semakin besar nilai Total Asset Turnover suatu perusahaan, maka Nilai Profitabilitas (ROA) akan semakin tinggi.

\section{PEMBAHASAN DAN HASIL}

\section{Pengaruh Receivable Turnover terhadap Profitabilitas $\left(\mathrm{H}_{1}\right)$}

Varibel Receivable Turnover menunjukkan nilai t-statistic sebesar -0.623 dengan nilai signifikan 0,5355 >0,05. Hal ini menunjukkan bahwa variabel Receivable Turnover tidak berpengaruh terhadap profitabilitas yang berarti bahwa hipotesis pertama ditolak. Pada dasarnya perusahaan sektor pertambangan memiliki laba perusahaan dominan yang dihasilkan dari perputaran piutang, karena penjualan secara kredit yang periodenya teratur maka tidak terlalu mengganggu perusahaan dalam perputaran labanya. Hal tersebutlah yang menjadi salah satu faktor yang menyebabkan Receivable Turnover tidak berpengaruh terhadap Profitabilitas perusahaan.

Hasil penelitian ini sesuai dengan penelitian yang dilakukan oleh Suarnami (2014) dalam penelitiannya diperusahaan pembiayaan yang menyatakan bahwa apabila suatu perusahaan menetapkan syarat pembayaran ketat berarti bahwa perusahaan lebih mengutamakan keselamatan kredit daripada pertimbangan profitabilitas. Syarat yang ketat misalnya dalam bentuk batas waktu pembayarannya yang pendek, pembebanan bunga yang berat pada pembayaran piutang yang terlambat. Dan penelitian ini tidak sejalan dengan yang dilakukan oleh Santhi (2014) dan Suminar (2014) yang menyatakan bahwa perputaran piutang terhadap profitabilitas. Semakin cepat perputaran piutang maka akan semakin kecil resiko manajemen dalam menginvestasikan dananya dalam bentuk piutang.

\section{Pengaruh Inventory Turnover terhadap Profitabilitas $\left(\mathbf{H}_{2}\right)$}


Varibel Inventory Turnover menunjukkan nilai t-statistik sebesar -0.536 dengan nilai signifikan $0.5939>0,05$. Hal ini menunjukkan bahwa variabel Inventory Turnover tidak berpengaruh terhadap profitabilitas yang berarti bahwa hipotesis kedua ditolak. Ketidakpengaruhan ini menunjukkan bahwa ketika Inventory Turnover tidak mengalami peningkatan atau penurunan maka profitabilitas akan tetap.

Hasil penelitian ini sesuai dengan penelitian Surya (2017) dengan objek perusahaan otomotif dan sparepart yang menyatakan bahwa dimana peningkatan persediaan menjadikan indikator akan terjadinya penurunan laba. Disamping itu juga ketika perusahaan menghadapi penjualan yang lambat sementara persediaan terus bertambah akan menambah biaya penyimpanan, resiko kerusakan tinggi dan juga adanya penurunan harga sehingga pengurangi pendapatan penjualan dan laba menjadi rendah. maka hasil penelitian ini tidak sesuai dengan hasil penelitian yang dilakukan oleh Naibaho dan Rahayu (2013) yang menyatakan bahwa perputaran persediaan berpengaruh positif terhadap profitabilitas. Artinya bahwa semakin cepat perputaran persediaan maka akan semakin tinggi tingkat profitabilitas perusahaan dan semakin rendah perputaran persediaan maka akan semakin rendah pula tingkat profitabilitas perusahaan.

\section{Pengaruh Working Capital Turnover terhadap Profitabilitas $\left(\mathrm{H}_{3}\right)$}

Varibel Working Capital Turnover pada t-statistik sebesar -1.363 dengan nilai signifikan $0,1782>0,05$. Hal ini menunjukkan bahwa variabel Working Capital Turnover tidak berpengaruh terhadap profitabilitas yang berarti bahwa hipotesis ketiga ditolak. Ketidakpengaruhan ini menunjukkan bahwa ketika perputaran modal kerja tidak mengalami peningkatan atau penurunan maka profitabilitas juga tidak ikut meningkat atau menurun secara searah.

Hasil penelitian ini sejalan dengan penelitian Sadewa (2016) dengan objek penelitiannya adalah perusahaan Wholesale and Ritel. Hal ini dikarenakan sumber modal kerja berasal dari banyak sumber tidak hanya berasal dari aktiva lancar, akan tetapi juga menggunakan modal sendiri, sehingga perbandingan modal kerja yang ditanamkan dalam perusahaan berpengaruh terhadap profitabilitas. Sebab lain karena present value (nilai sesungguhnya) dari aktiva lancar yang membentuk komponen modal kerja yaitu piutang, persediaan dan kas, seperti contohnya pada perusahaan yang mempunyai jumlah piutang yang sangat besar akan tetapi ada beberapa piutang tersebut sudah terjadi lama transaksinya dan sulit tertagih sehingga nilai realisasinya mungkin lebih kecil dibandingkan dengan yang dilaporkan, serta perubahan persediaan dalam hubunganya dengan volume penjualan sekarang atau dimasa yang yang akan datang, yang mungkin adanya over invesmentdalam persediaan hal-hal tersebut yang mempengaruhi moda yang menyatakan bahwa maka hasil penelitian ini tidak sesuai yang dilakukan oleh Yuliati (2012) dan Mulatsih (2014) yang menyatakan bahwa perputaran modal kerja berpengaruh positif terhadap profitabilitas. Yang menyatakan bahwa dapat diketahui jika modal kerja memegang peranan yang sangat penting terhadap efisiensi perusahaan. Semakin tinggi tingkat perputaran modal kerja berarti bahwa perusahaan mampu mengoptimalkan tingkat pemakaian modal kerja dalam kegiatan operasionalnya dalam rangka memperoleh laba

\section{Pengaruh Total Asset Turnover terhadap Profitabilitas $\left(\mathbf{H}_{4}\right)$}

Varibel Total Asset Turnover menunjukkan nilai t-statistik sebesar 1,171 dengan nilai signifikan 0,252 >0,05. Hal ini menunjukkan bahwa variabel perputaran total aset berpengaruh Positif signifikan terhadap profitabilitas yang berarti bahwa hipotesis 
keempat diterima. Pengaruh positif menunjukkan ketika perputaran total aset mengalami peningkatan maka profitabilitas ikut meningkat secara searah.

Hasil penelitian ini sejalan dengan penelitian Rahmah dkk (2012) yang memyatakan bahwa perputaran total aset berpengaruh positif signifikan terhadap profitabilitas. Apabila dalam menganalisis rasio TATO selama beberapa periode menunjukan suatu hal yang cenderung meningkat, maka dapat memberikan gambaran bahwa semakin efisisen penggunaan aktiva sehingga meningkat. TATO dipengaruhi oleh besar kecilnya pendapatan dan total aktiva, baik aktiva lancar maupun aktiva tetap. Dengan demikian sangat dimungkinkan bahwa hubungan antara TATO dengan Return On Asset (ROA) adalah positif. maka hasil penelitian ini tidak sesuai yang dilakukan oleh Sari (2014).

\section{KESIMPULAN DAN SARAN \\ Kesimpulan}

Berdasarkan hasil analisis dan pembahasan yang telah diuraikan, maka kesimpulan dari penelitian ini sebagai berikut:

a. Receivable Turnover tidak memiliki pengaruh signifikan terhadap profitabilitas. Dari hasil uji t dapat dilihat bahwa Receivable Turnover memiliki nilai signifikan 0,5355. Nilai ini lebih besar dari nilai probabilitas yaitu 0,05 atau nilai $0,5355>0,05$. Pada uji $\mathrm{t}$ juga dapat dilihat bahwa Receivable Turnover memiliki nilai t-statistic $_{\text {sebesar }-0.623}$ nilai ini dibawah nilai $t_{\text {tabel }}$ sebesar 2.011. Maka dapat disimpulkan Receivable Turnover tidak berpengaruh terhadap profitabilitas.

b. Inventory Turnover tidak memiliki pengaruh signifikan terhadap profitabilitas. Dari hasil uji t Inventory Turnover memiliki nilai signifikansi sebesar 0.5939. Nilai ini lebih besar dari nilai probabilitas yaitu 0,05 atau nilai $0.5939>0,05$. Pada uji t juga

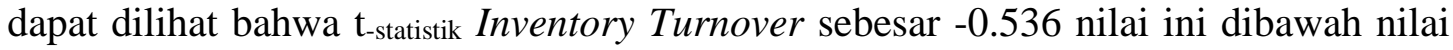
tabel sebesar 2.011. Maka disimpulkan Inventory Turnover tidak berpengaruh signifikan terhadap profitabilitas.

c. Working Capital Turnover kerja tidak memiliki pengaruh signifikan terhadap profitabilitas. Dari hasil uji t Working Capital Turnover memiliki nilai signifikansi sebesar 0,1782 . Nilai ini lebih besar dari nilai probabilitas yaitu 0,05 atau nilai 0,1782>0,05. Pada uji t juga dapat dilihat bahwa tstatistik $_{\text {Working Capital Turnover }}$ sebesar -1.363 nilai ini dibawah nilai tabel sebesar 2.011. Maka disimpulkan Working Capital Turnover tidak berpengaruh signifikan terhadap profitabilitas.

d. Total Asset Turnover tidak memiliki pengaruh signifikan terhadap profitabilitas. Dari hasil uji t Total Asset Turnover memiliki nilai signifikansi sebesar 0,252. Nilai ini lebih besar dari nilai probabilitas yaitu 0,05 atau nilai $0,252>0,05$. Pada uji t juga dapat dilihat bahwa Total Asset Turnover menunjukkan nilai t-statistik sebesar 4,859 nilai ini diatas nilai tabel sebesar 2.011. Maka disimpulkan perputaran total aset berpengaruh Positif signifikan terhadap profitabilitas.

\section{Saran}

Untuk peneliti selanjutnya sebaiknya periode penelitian yang digunakan ditambah serta sampel yang digunakan dapat ditambah atau di perluas pada sektor perusahaan yang lain. Peneliti selanjutnya diharapkan dapat menambah rasio aktivitas yang lainnya 
dan rasio pengukuran lain dari rasio lainnya untuk menguji kembali variabel dalam penelitian selanjutnya terutama yang dapat mempunyai tingkat hubungan laba usaha.

\section{DAFTAR PUSTAKA}

Ahsanti, Eva "Analisis Pengaruh Manajemen Modal Kerja, Likuiditas, Leverage, Aktivitas dan Ukuran Perusahaan Terhadap Tingkat Profitabilitas Perusahaan (Skripsi S1 Fakultas Ekonomi dan Bisnis, Universitas Islam Negeri Syarif Hidayatullah Jakarta, 2016)

Alfredo et al., "Pengaruh Kinerja Keuangan Terhadap Nilai Perusahaan Pasar Perusahaan Manufaktur di Bursa Efek Indonesia". Jurnal Manajemen,

Strategi Bisnis, dan Kewirausahaan Vol.6, No.2, Agustus 2012.

Alivia, Natasha Rizky, "Analisis Faktor-Faktor Yang Mempengaruhi Nilai Perusahaan Dengan Profitabilitas Sebagai Variabel Intervening (Skripsi S1 Fakultas Ekonomi dan Bisnis Universitas Diponegoro, 2013)

Ambarwati et al., "Pengaruh Modal Kerja, Likuiditas, Aktivitas dan Ukuran Perusahaan Terhadap Profitabilitas". ". E-Jurnal Akuntansi, Universitas Pendidikan Ganesha, Vol.3 No.1, 2015.

Astuti, Dewi, Manajemen Keuangan Perusahaan, (Jakarta: Ghalia Indonesia, 2004).

Barakat, Abdallah, "The Impact of Financial Structure, Financial Leverage and Profitability on Industrial Companies Share Value". Journal of Finance and Accounting, Shaqra University Vol.5, No.1. 2014.

Brigham, E. F., dan Houston, J. F, Manajemen Keuangan, (Edisi 8. Jakarta: Erlangga, 2001).

Carningsih, Pengaruh Good Corporate Governance Terhadap Hubungan Antar Kinerja Keuangan Dengan Nilai Perusahaan, (Skripsi S1 Fakultas Ekonomi Universitas Guna Dharma, 2012).

Fahmi, Irham, Pengantar Manajemen Keuangan Teori dan Soal Jawab, (Edisi 1, Bandung: Alfabeta, 2013)

Ghozali, Imam, Model Persamaan Struktur Konsep dan Aplikasi dengan Program Amos 16.0, (Semarang: Badan penerbit UNDIP, 2008)

Harahap, Sofyan, Syafiri, Analisis Kritis Atas Laporan Keuangan, (Jakarta: Raja Grafindo Persada, 2010).

Harjito, A dan Martono, Manajemen Keuangan. (Yogyakarta: Ekonisia, 2005)

Haryono, Siswoyo dan Wardoyo, Parwoto, Structural Equation Modeling, (Jakarta: Intermedia Personalia Utama, 2012)

Hasan, Iqbal, Pokok-pokok Materi Statistik 2 (Statistik Infrensif), (Edisi Kedua. Jakarta: Bumi Aksara, 2010).

Husaini, U., dan Setiady, A, P, Pengantar Statistik. (Edisi Kedua. Jakarta: PT. Bumi Aksara, 2006).

Husnan, Suad dan Enny Pudjiastuti. Dasar-Dasar Manajemen Keuangan. (Edisi 6. UPP STIM YKPN. Yogyakarta, 2002).

Imanudin, et all. "Pengaruh Struktur Modal Terhadap Kinerja Perusahaan". Jurnal Wawasan Manajemen. Vol.2 No.1 Februari 2014.

Sari, Indah P. dan Abundanti, Nyoman, "Pengaruh Pertumbuhan Perusahaan dan Leverage terhadap Profitabilitas dan Nilai Perusahaan". Jurnal Fakultas Ekonomi dan Bisnis Universitas Udayana, Bali, 2014. 
Indiasari, Rima, “Analisis Struktur Kepemilikan Perusahaan, Faktor Intern, Kebijakan Dividen, Faktor Makro Ekonomi dan Struktur Modal terhadap Nilai Perusahaan (Skripsi S1 Fakultas Ekonomi dan Bisnis, Universitas Islam Negeri Syarif Hidayahtullah Jakarta, 2011)

Kasmir, Pengantar Manajemen Keuangan, (Jakarta: Kencana, 2010).

Kasmir, Analisis Laporan Keuangan, (Jakarta: PT Raja Grafindo Persada, 2012).

Kenneth, Marangu \& Ambrose, Jagongo, "Price to Book Value and Financial Statement Variables". Journal School of Business, Kenyatta University Vol.3(6):50-56. 2014

Moeljadi, Manajemen Keuangan Pendekatan Kuantitatif dan Kualitatif, (Edisi Pertama. Malang: Bayu Media Publishing, 2006).

Munawir, S, Analisis Laporan Keuangan. (Edisi Keempat. Yogyakarta: Liberty, 2010).

Nasarudin, Indo Yama dan Fauzan, Hemmy. Pengantar Bisnis dan Manajemen, (Jakarta: UIN Jakarta Press, 2006).

Putri, Anggraeni Ichsani, "Analisis Pengaruh Debt to Equity Ratio, Net Profit Margin, dan Total Asset Turnover Terhadap Return On Equity Serta Dampaknya Terhadap Nilai Perusahaan", (Skripsi S1 Fakultas Ekonomi dan Bisnis, Universitas Islam Negeri Syarif Hidayatullah Jakarta, 2011).

Riadi, Edi. Aplikasi Lisrel untuk Penelitian Analisis Jalur. (Edisi 1, Yogyakarta: ANDI, 2013).

Riyanto, B. "Dasar-Dasar Pembelanjaan Perusahaan", (Edisi Keempat, Yogyakarta: BPFE Universitas Gadjah Mada, 2011).

Rodoni, Ahmad dan Herni Ali. "Manajemen Keuangan”. (Edisi 1. Jakarta: Mitra Wacana Media, 2010).

Rompas, Gisela Prisilia, "Pengaruh Likuiditas, Solvabilitas, dan Rentabilitas terhadap Nilai Perusahaan BUMN yang terdaftar di Bursa Efek Indonesia”. Jurnal EMBA, 1(3), 2013, h:252-262

Sadewa, Rio. Pengaruh Perputaran Modal Kerja dan Perputaran Piutang Terhadap Profitabilitas Pada Perusahaan Wholesale and Ritel Yang Terdaftar di BEI tahun 2013- 2015. Jurnal mahasiswa dinus. 2016

Sarjono, Haryadi dan Julianita, Winda, SPSS vs LISREL, (Jakarta: Salemba Empat, 2010).

Sartono, A. Manajemen Keuangan: Teori dan Aplikasi, (Edisi 4, Yogyakarta: BPFE Universitas Gadjah Mada, 2011).

Sefiani, Kartika dan Sitohang, Sonang, "Pengaruh Current Ratio, Total Asset Turnover, dan Umur Perusahaan Terhadap Profitabilitas”. Jurnal STIESIA Surabaya, 2016.

Sofyaningsih, Sri dan Hardiningsih, Pancawat, "Struktur Kepemilikan, Kebijakan Dividen, Kebijakan Hutang dan Nilai Perusahaan”. Dinamika Keuangan dan Perbankan. Vol. 3 No. 1, Mei 2011, pp 68-87

Suarnami, Luh Komang \& Wayan Suwendra, Wayan Cipta. Pengaruh Perputaran Piutang Dan Periode Pengumpulan Piutang Terhadap Profitabilitas Pada Perusahaan Pembiayaan. e-Journal Bisma Universitas Pendidikan Ganesha. Jurusan Manajemen. Volume 2 Tahun. 2014.

Sugiyono, Statistika Untuk Penelitian, (Jakarta: CV. ALFABETA, 2009).

Surya, Sarjito \& Ruly Ruliana, Dedi Rossidi Soetama. Pengaruh Perputaran Kas dan Perputaran Persediaan Terhadap Profitabilitas. Akuntabilitas: Jurnal Ilmu 
Akuntansi Volume 10 (2), Oktober 2017 P-ISSN: 1979-858X; E-ISSN: 24611190 Page 313 - 332

Syarif, “Analisis Pengaruh Kinerja Keuangan Terhadap Nilai Perusahaan”, (Skripsi S1

Fakultas Ekonomi dan Bisnis, Universitas Muhammadiyah Surakarta, 2014).

Tampubolon, Manahan, Manajemen Keuangan (Finance Management), (Edisi 1, Jakarta: Mitra Wacana Media, 2013).

Weston, J. Fred., dan Thomas E. Copeland, Manajemen Keuangan, (Edisi 8. Jilid 1. Alihbahasa: Jaka Wasana dan Kirbrandoko. Gelora Aksara Pratama, Jakarta, 1995).

Wulandari, Cici "Analisis Pengaruh Return On Assets, Earning Per Share, Debt to Equity Ratio Terhadap Price to Book Value Pada Perusahaan Manufaktur (Skripsi S1 Fakultas Ekonomi dan Bisnis, Universitas Muhammadiyah Surakarta, 2015)

www.idx.co.id

www.pdfsearchengine.org

www.SSRN.com

www.ticmi.co.id 